\title{
瀧口克已氏の討論に封する回答
}

\section{THE AUTHERS' ANSWERS TO THE DISCUSSION BY PROF. KATSUKI TAKIGUCHI}

(Katsuki TAKIGUCHI, J. Struct. Constr. Eng. AIJ, No. 543, 191-192, May 2001)

\author{
浜田公也*, 中西靖 直**, 南 宏一*** \\ Kimiya HAMADA, Yasunao NAKANISHI and Koichi MINAMI
}

The authors' answers to discussion by Prof. K.Takiguchi are as follows.

1) The values are calculated correctly. But expression of some sentences is opposite.

2) The value of Qexp/Qcal is $0.95 \sim 1.53$ and average value is 1.18 when the axial force ratio is $0 \sim 0.3$. The value of Qexp/Qcal is $0.90 \sim 1.28$ and average value is 1.28 when the axial force ratio is $0.3 \sim 0.5$.

3) There are must be some difference between the calculated value and experimental value by a assumption. It's important considering the difference in structural design.

Keywords : reinforced concrete column, half-precast, centrifugal casting, discussion, calculated value, experimental value 鉄筋コンクリート柱，ハーフプレキャスト，遠心成形，討論，計算値，実験值

\section{1.はじめに}

遠心成形ハーフプレキャスト角型管の終局強度に関する筆者等の 論文1)（以下、該論文と呼ぶ）に対して、ご丁血なご意見をいただ きましてありがとうございました。ご質問について検討した結果を 以下に述べさせていただきます。

\section{2. 結語の記述について}

「実験值を計算值で除した強度比の値は全体てはおよそ0.9〜1.4 の範囲にあり、平均值は1.15であった」との記述と「誘導された方 程式は、実験值に較べて・.・・1 2 割程度大きく評価する」と の記述は、逆の意味ではないかとのご指摘については、ご指摘の通 りです。前者の記述は、実験值之該論文で誘導されている方程式に よる計算値から求めた実験値／計算値の值について示したもので、 検討結果として適切であると考えます。しかし、後者の記述は、設 計の参考にするため、対象とする柱の強度を方程式を用いて推定す る場合、実際の強度はどの程度の余裕があるのかを示そうとしたも のですが、表現が不適切でした。「大きく評価する」を「小さく評 価する」に訂正します。このような表現は、5. 結語の他、4.2 実験 值亡計算值との強度比 $\mathrm{Q} \exp / \mathrm{Q}$ cal 亡各要因の関係、4.3 精度の検 証結果 の文章中にもありますので、読者の方にはお詫びをすると ともに訂正のお願いをします。

\section{3． 軸力比の影響について}

$\mathrm{n}-\mathrm{q}$ 相関方程式における特定点 $\mathrm{n}_{0} \sim \mathrm{n}_{7}$ の值は、試験体におけ る断面の形状寸法、主筋の量 - 強度、横補強筋の量 - 強度、材料強 度等により変化するため、軸力比の値とは直接関係ありません。軸 力比の影響について示そうとしたために、軸力比の值を低および中
レベル程度の軸力として0〜0.3、0.3〜0.5の範囲に分けた、という 以外には特別な意味はありません。また、Q exp $/ \mathrm{Q}$ calの值は、軸 力比が $0 \sim 0.3$ 範囲では $0.92 \sim 1.53$ て平均值は $1.18 、 0.3 \sim 0.5$ の範 囲では0.90〜1.28で平均値は1.06です。この值を基に $1 \sim 2$ 割程度 および同程度という記述をしました。

次に、軸力比が零で計算值が式(15)で求められた資料の取り扱い 方が不明とのご指摘についてですが、軸力比が零でも式(15)が該当 するのかとのご指摘かと思われます。これについては、圧縮力が零 でも式(15)が該当する場合があります。該当する 3 体の試験体は、 特に主筋の降伏引張強度が大きく、式(15)に対応する圧縮力の下限 值を表す特定点 $\mathrm{n}_{3}$ の值が負になっています。これら 3 体の試験体 について、圧縮力 $\mathrm{N}$ と断力 $\mathrm{Q}$ 関係を図一 $\mathrm{A}$ に示します。太い 実線が該論文の $N-Q$ 関係、の印が特定点、@が実験值を表し、ト ラス機構、アーチ機構、中段筋による $\mathrm{N}-\mathrm{Q}$ 関係も併記しています。 また、既報2つで提案した圧縮と曲げを受ける場合の終局強度の評価 式によるN-Q関係を一点鎖線、同じ評価式によるが補正係数を無 視した全塑性モーメントによる $\mathrm{N}$-Q $\mathrm{Q}$ 関係を破線で示しています。

\section{4. 計算値と実験値の差異について}

まず、ご指摘の該論文の表 -2 と図一 9 は異なる場合があるかど うかについてですが、同じデータを使用しており異なることはあり ません。ところが、筆者等の不注意で、図-9の作成時に縦軸の值 を小さく設定したことにより、試験体 3 体分の情報が示されており ませんでした。図ーAに示した 3 体分です。改めて、実験值 $\mathrm{Q} \exp$ 亡計算値Q cal の関係を図ーBに示します。このことにより、実験 值は23. 7〜211tfの範囲になります。

さて、圧縮曲げせん断を受ける鉄筋コンクリート柱で、曲げ系の

\footnotetext{
* 侏)ピー・エ又建築技術部 主任研究員・博士 (工学)

** 三装建設侏技術研究所 所長・博士 (工学)

*** 福山大学上学部建築学科 教授・工博
}

\author{
Senior Research Engineer, Research \& Engineering Dept., P.S. Corporation, \\ Dr. Eng. \\ General Manager, Technical Research Institute, Mitsubishi Construction Co., Ltd. \\ Dr. Eng. \\ Prof., Dept. of Architecture, Faculty of Eng., Fukuyama Univ., Dr. Eng.
}




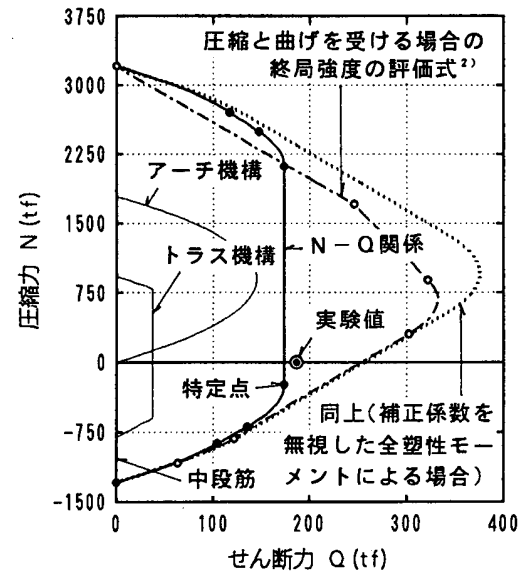

(a) 試験体名 No. $6 \mathrm{R}$

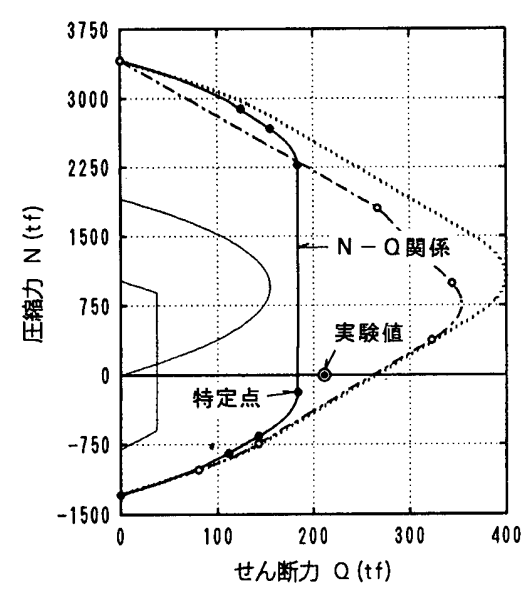

(b) 試験体名 No. 7L

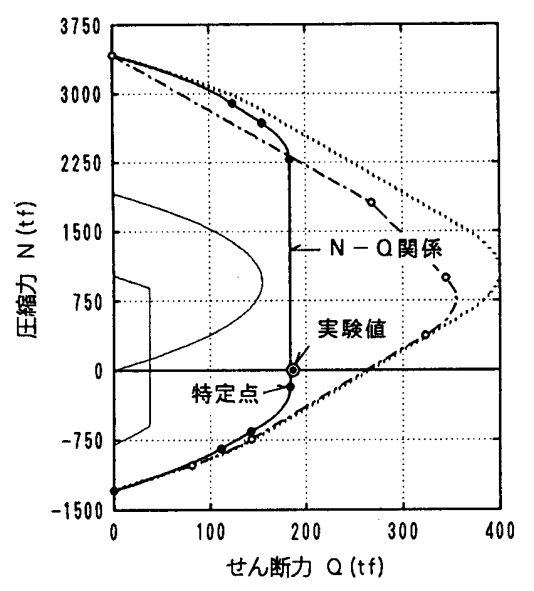

(c)試験体名 No.7R

図一 A 圧縮力 $\mathrm{N}$ とせん断力 Qの関係（試験体名は該論文の表一 2 に対応する）

破壊を示すものに関しては、ストレスブロックや平面保持の仮定を 用いて計算した值と実験值とては差が生じる場合があることに対し て、筆者等の考えを求められておりますので意見を述べます。

該論文で示した曲げ系の破壊を示している試験体の計算値は、ほ ぼ下限值を予測しております。その要因の 1 つとして、終局強度の 評価式の選択が考えられます。該論文て提案した圧縮・曲げ・せん 断を受ける場合の終局強度の評価式と既報 2)で提案した圧縮亡曲げ を受ける場合の終局強度の評価式とでは、 $\mathrm{N}-\mathrm{Q}$ 相互作用曲線で比 較した場合、概略ではありますが、式(12)近辺ではあまり差はなく、 式(13) 式(14)近辺では前者に較べ後者が大きくなる傾向がありま す（該論文の図-6、図-7参照）。該論文では前者で終局強度を 評価しており、後者で評価するよりは、若干小さめに評価されてい ることが考えられます。

一方、一体打ち鉄筋コンクリート柱について、阿部 ${ }^{32}$ は、平面保 持の仮定を用いて求めた曲げ終局耐力に較べて、実験值は大きくな る傾向を示し、圧壊がある程度進んている断面の曲げ終局耐力は、 フェイス位置より上部の断面位置での曲げ応力とすべきであると指 摘し、討論者ら (2 〜) は、圧縮・曲げ・せん断を受ける場合の危険 断面の圧縮曲げ強度は、ストレスブロックを仮定して算定する際に は、応力値の割増しを考慮する必要があることを示しています。ま た、渡辺ら ${ }^{8}$ は、超高強度コンクリート柱について、ストレスブロ ックを用いる亡、柱曲げ強度のほぼ下限を予測できるが、コンクリ 一ト強度が小さくなれば、また軸力が大きくなると実験值を過小評 価することを報告しています。この場合、拘束コンクリートによる 圧縮強度の増加では説明が難しいことも報告されています。

このように、平面保持やストレスブロックを仮定して求められた 曲げ強度は実験值を過小評価する場合がありますが、その原因は明 確になっていないのが現状であると考えます。該論文で対象として いる強度の異なるコンクリートで構成された柱についても、同様の 傾向が認められるものもあり、終局強度の評価に中央部分で澎らん だ形のアーチ機構" ‘導入することも考えられますが、定量化する までには至っておりません。筆者等は、終局強度を小さめてはなく 適切に評価されることが望ましいと考えています。しかしながら、 現状では計算值と実験値に差が生じることはやむを得ず、その差の 程度を考慮して設計に利用することも重要であると考えます。

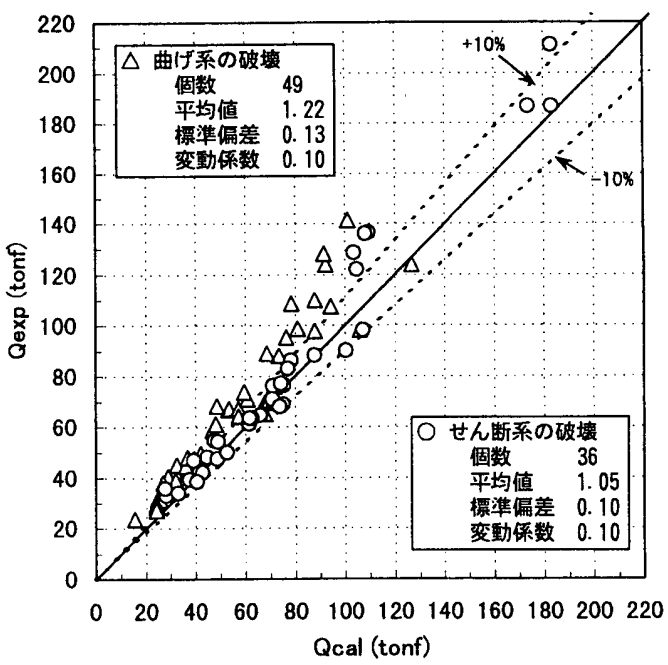

図-B 実験値Q $\exp$ 亡計算值Q cal の関係

\section{参考文献}

1)近田公也、中西靖直、南宏一：圧樎・曲げ・せ九断を受ける遠心成形八一 フプレキャスト角型管を用いた鉄筋コンクリート柱の終局強度、日本建築 学会構造系論文集、第532号、pp. 127-136、2000.6

2)捠田公也、中西靖直、南宏一：遠心成形ハーフプレキャスト角型管を用い た鉄筋コンクリート柱の累加強度法による終局曲け強度、日本建築学会構 造系論文集、第511号、pp.123-132、1998. 9

3)阿部浩一：全軸力籍囲における鉄筋コンクリート柱の主軸および対角軸曲 げ終局耐力算定式の一提案、コンクリート工学論文、Vol. 23、No. 9、 pp. 107-117、Sept. 1985

4)瀧口克己、堀田久人、淟㴊知已、森田修平：R C 柱端部コンクリートの圧 樎特性に関する基䃈実験、日本建築学会構造系論文報告集、第442号、 pp. 123-131、1992.12

5)瀧口克己、森田修平：偏心圧縮を受ける $\mathrm{R} / \mathrm{C}$ 部材におけるコンクリート の圧縮挙動、日本建築学会構造系論文集、第464号、pp.109-118、1994.10

6)瀧口克己、宮崎裕一、溝判知已：逆対称偏心圧縮を受ける $\mathrm{R} / \mathrm{C}$ 柱端部ב ンクリートの圧縮特性、日本建築学会構造系論文集、第478号、 pp. 143-151、1995. 12

7)瀧口克己、今井和正、溝渕知巳 : 圧縮曲げせん断を受ける $R / C$ 柱端部ב ンクリートの圧縮強度、日本建築学会構造系論文集、第 496 号、 pp. 83-90、1997. 6

8)渡辺史夫、西山峰広、六車熙：超高強度コンクリートを用いた R C 柱の曲 強度之勒性、日本建築学会構造系論文報告集、第446号、pp. 99-106、 1993.4

9)若林賽・南宏一：鉄筋コンクリート柱のせん断破壊防止法に関する実験的 研究、京大防災研究所年報、第22号B-1、pp. 295-316、昭54.4

(2001年: 2 月 9 日原稿受理，2001年 2 月13日採用決定) 